Cilt/Volume:13 Sayı/Issue:3 Aralık/December 2021 Özel Sayı/Special Issue

\title{
Effects of Heat Treatment on the Hardness Properties and Microstructure of Al-6505 Alloy
}

\author{
Che Nor Aiza Jaafar ${ }^{1}$ iD, Ismail Zainol ${ }^{2}$ iD, Recep Calin $^{3}$ iD \\ ${ }^{1}$ Department of Mechanical and Manufacturing Engineering,,Universiti Putra Malaysia, 43000 Serdang Selangor, MALAYSIA \\ ${ }^{2}$ Department of Chemistry, Sultan Idris Education University, 35900 Tanjung Malim, Perak, MALAYSIA. \\ ${ }^{3}$ Department of Metallurgy and Material Science Engineerin, Kirikkale University, 71450 Kirikkale, TURKEY
}

Başvuru/Received: 07/10/2021

Kabul / Accepted: 25/12/2021

Çevrimiçi Basım / Published Online: 31/12/2021

Son Versiyon/Final Version: 31/12/2021

\begin{abstract}
The effects of heat treatment on the ageing response, hardness properties and the microstructure development of Al-6505 alloy have been investigated. In order to study these effects, the alloy sample was solution treated at $550^{\circ} \mathrm{C}$ for 30 minutes and then quenched into cold water at room temperature followed by artificially aged at elevated temperature of $100 \mathrm{oC}, 185 \mathrm{oC}$ and $300 \mathrm{oC}$. The ageing response of Al-6505 alloy was monitored using Vickers hardness test. The distribution of the precipitates formed in Al-6505 alloy was monitored by transmission electron microscopy (TEM). The results showed that time to reach peak hardness and peak hardness values decreased as the ageing temperatures increased. It was found that increasing in hardness values of the alloy were due to needle-shaped precipitates formation during ageing treatment. Prolonged ageing time to over-aged condition resulting in increased the size but reduced the number of precipitates; as a result the hardness of Al-6505 alloy was reduced. The effects of heat treatment on the ageing response, hardness properties and the microstructure development of Al-6505 alloy have been investigated. In order to study these effects, the alloy sample was solution treated at $550^{\circ} \mathrm{C}$ for 30 minutes and then quenched into cold water at room temperature followed by artificially aged at elevated temperature of $100 \mathrm{oC}, 185 \mathrm{oC}$ and $300 \mathrm{oC}$. The ageing response of Al-6505 alloy was monitored using Vickers hardness test. The distribution of the precipitates formed in Al-6505 alloy was monitored by transmission electron microscopy (TEM). The results showed that time to reach peak hardness and peak hardness values decreased as the ageing temperatures increased. It was found that increasing in hardness values of the alloy were due to needle-shaped precipitates formation during ageing treatment. Prolonged ageing time to over-aged condition resulting in increased the size but reduced the number of precipitates; as a result the hardness of Al-6505 alloy was reduced.
\end{abstract}

\section{Key Words}

"Al-6505 alloy, heat treatment, ageing response, hardness, microstructure" 


\section{Introduction}

The 6000 series of Al-Mg-Si alloys has been used in many sectors and industries such as automotive, construction and defense industries due to its high strength-to-weight ratio, good formability and resistance to corrosion (Zhenguo et al., 2021). The mechanical properties of 6000 series containing $\mathrm{Mg}$ and $\mathrm{Si}$ are known to be improved by heat treatment process. This type of alloys can be strengthened by the formation of precipitates (hardening phase) during heat treatment process which involved three main steps: solution treatment, quenching and ageing. The solution treatment process consists of heating the alloys containing alloying elements between $450 \mathrm{oC}$ and $550 \mathrm{oC}$ and soaking them for a period of time to dissolve the alloying elements into a solid solution. Quenching is done afterward purposely to retain the maximum amounts of alloying elements in solid solution. Meanwhile ageing or artificial ageing is the final stage in development of properties in the 6000 series alloys. The high strength of alloys is obtained through precipitation hardening at paint bake heat treatment.

Generally, the presence of $\mathrm{Mg}$ and Si contents in the alloy results in the formation of needle shaped precipitates (hardening phase). The strength of the alloy derives from the ability of precipitates to stop dislocation motion (Emma and Salem, 2010). It can be noticed that time and temperature is the main parameters in heat treatment process that needed to be considered to obtain the optimum mechanical properties of the alloy. For 6000 series alloys, the range of temperature used for artificial ageing (T6) is between 160 oC and 190 oC (Polmear, 2017). Normally fast ageing response appears when the alloys are artificially aged at higher temperature. The objectives of this study are to investigate the effects of heat treatment process on the ageing response, hardness properties and microstructural development by using Vickers hardness test and TEM analysis.

\section{Methodology}

The alloy used in this study is Al-6505 alloy from 6000 series alloy. The alloy was obtained in extruded form of 40 mm wide and 4 mm thick. The chemical composition of Al-6505 alloy is tabulated in Table 1.

Table 1. Chemical compositions of 6000 series alloys (wt.\%)

\begin{tabular}{|c|c|c|c|c|c|c|}
\hline Alloy & Mg & Si & Mn & Fe & Cu & Ti \\
\hline 6505 & 0.40 & 0.45 & 0.031 & 0.17 & 0.002 & 0.012 \\
\hline
\end{tabular}

The Al-6505 alloy sample was solution treated in an electrical muffle furnace at $550{ }^{\circ} \mathrm{C}$ for 30 minutes followed by a quench into cold water and then it was immediately artificially aged in a muffle furnace at different ageing temperatures of $100{ }^{\circ} \mathrm{C}, 185{ }^{\circ} \mathrm{C}$ and $300{ }^{\circ} \mathrm{C}$ between 0.1 to 1000 hours. The ageing response for the alloy was monitored by means of Vickers hardness tester. For each sample, five hardness readings were taken to ensure an accurate reading and the average value of hardness was determined. The hardness curve was plotted using a logarithmic time axis. TEM was carried out on overaged alloy Al-6505 alloy which had been aged at $300{ }^{\circ} \mathrm{C}$ for $0.1,1$ and 100 hours after solution treatment. TEM analysis was performed on the Al-6505 alloy in order to examine the microstructural development and precipitates distribution with different alloy conditions.

\section{Results and Discussion}

\section{Effect of heat treatment on ageing response and hardness properties}

The hardness curves for Al-6505 alloy after ageing at $100{ }^{\circ} \mathrm{C}, 185^{\circ} \mathrm{C}$ and $300{ }^{\circ} \mathrm{C}$ is presented in Figure 1 . From hardness measurement, it is seen that the hardness increased slowly up to 1 hour and the peak hardness is reached eventually at different ageing temperatures. However no peak hardness observed for the alloy that aged at $100 \mathrm{oC}$ up to 1000 hours. The final hardness of the alloy decreases with increasing ageing temperature and this is referred to over-aged condition. Table 2 shows time to reach peak hardness and peak hardness value for Al-6505 alloys that artificially aged at different ageing temperatures. In increasing in hardness values during ageing treatment has been related to the formation of hardening precipitates in the alloy. These precipitates interference the dislocation motion, thus the hardness of alloy is increased (Polmear, 2017). It can be seen that the peak hardness are reached most rapidly (1 hour) at the higher ageing temperature but the hardness values decrease as the ageing temperature is increased. This can be explained that the higher the ageing temperature (up to $300 \mathrm{oC}$ ), the faster the rate of formation resulted the larger the precipitates formed at shorter ageing time (Aiza et al., 2015)]. This situation leads to give lower peak hardness value (43.10 VHN) for the higher ageing temperature. 


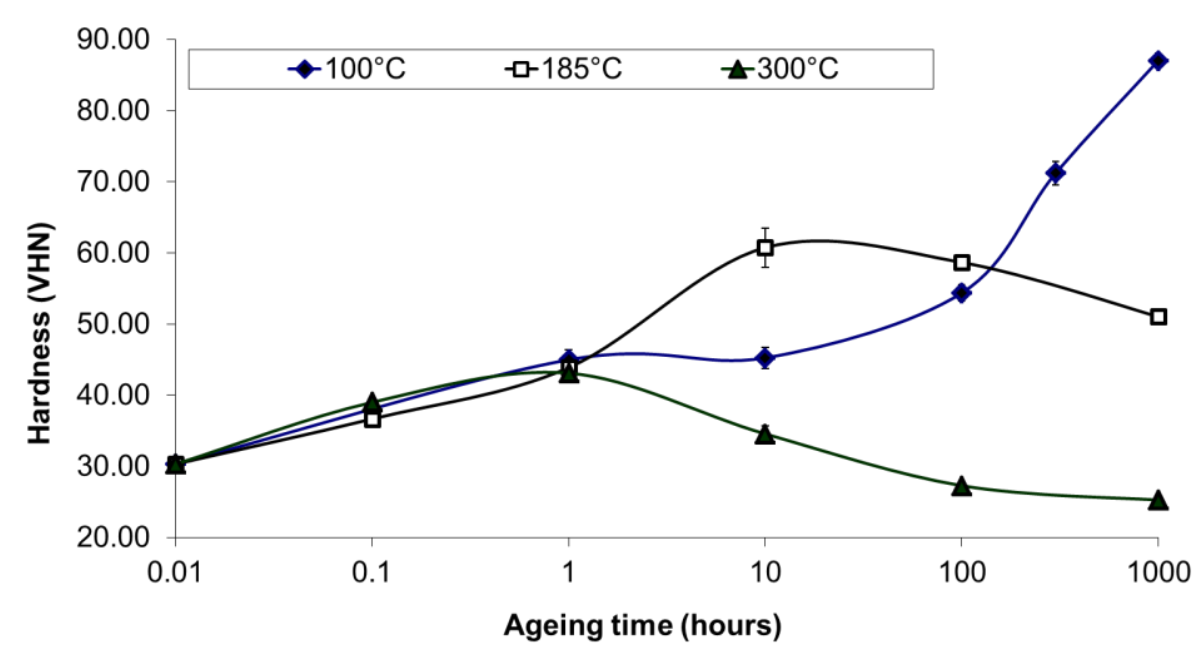

Figure 1. Ageing curves of Al-6505 alloy at different ageing temperatures of $100{ }^{\circ} \mathrm{C}, 185^{\circ} \mathrm{C}$ and $300{ }^{\circ} \mathrm{C}$

Table 2. Time to reach peak hardness and peak hardness values of Al-6505 alloy that artificially aged at different ageing temperatures

\begin{tabular}{|c|l|l|l|}
\hline $\begin{array}{c}\text { Ageing Temperature } \\
\left({ }^{\circ} \mathbf{C}\right)\end{array}$ & $\mathbf{1 0 0}^{\circ} \mathbf{C}$ & $\mathbf{1 8 5}^{\circ} \mathbf{C}$ & $\mathbf{3 0 0}^{\circ} \mathbf{C}$ \\
\hline $\begin{array}{c}\text { Time to reach } \\
\text { peak hardness (hours) }\end{array}$ & - & 10 & 1 \\
\hline $\begin{array}{c}\text { Peak hardness value } \\
(\mathrm{VHN})\end{array}$ & - & 60.75 & 43.10 \\
\hline
\end{tabular}

Microstructure analysis

Figure 2 shows TEM analysis of the Al-6505 alloy after artificially aged at $300^{\circ} \mathrm{C}$ for $0.1,1$ and 100 hours, respectively. This alloy conditions are referred to under-aged ( 0.1 hour), peak-aged ( 1 hour) and close to peak-aged (100 hours). Few if any precipitates were observed in Al-6505 alloy at the short ageing time at 0.1 hour (under-aged). Prolong ageing time for 1 hour (peak aged) results in increased the distribution of needle-shaped of precipitates associated with high density of dislocation loops in the alloy. This precipitate is considered to be the most efficient strengthening in 6000 series alloys (Aiza et al., 2011; Mingjun et al., 2020). These precipitates hindered the movement of dislocation, hence the alloy was strengthened. Further ageing to 100 hours led to increase the precipitates size and length but decrease in precipitates density. At this stage it is more favourable for the dislocation to pass precipitates via Orowon mechanism, leading to a decrease in hardness and strength of the alloy (Emma and Salem, 2010). The TEM analysis results are consistent with the results of hardness test of temperature at $300^{\circ} \mathrm{C}$. 

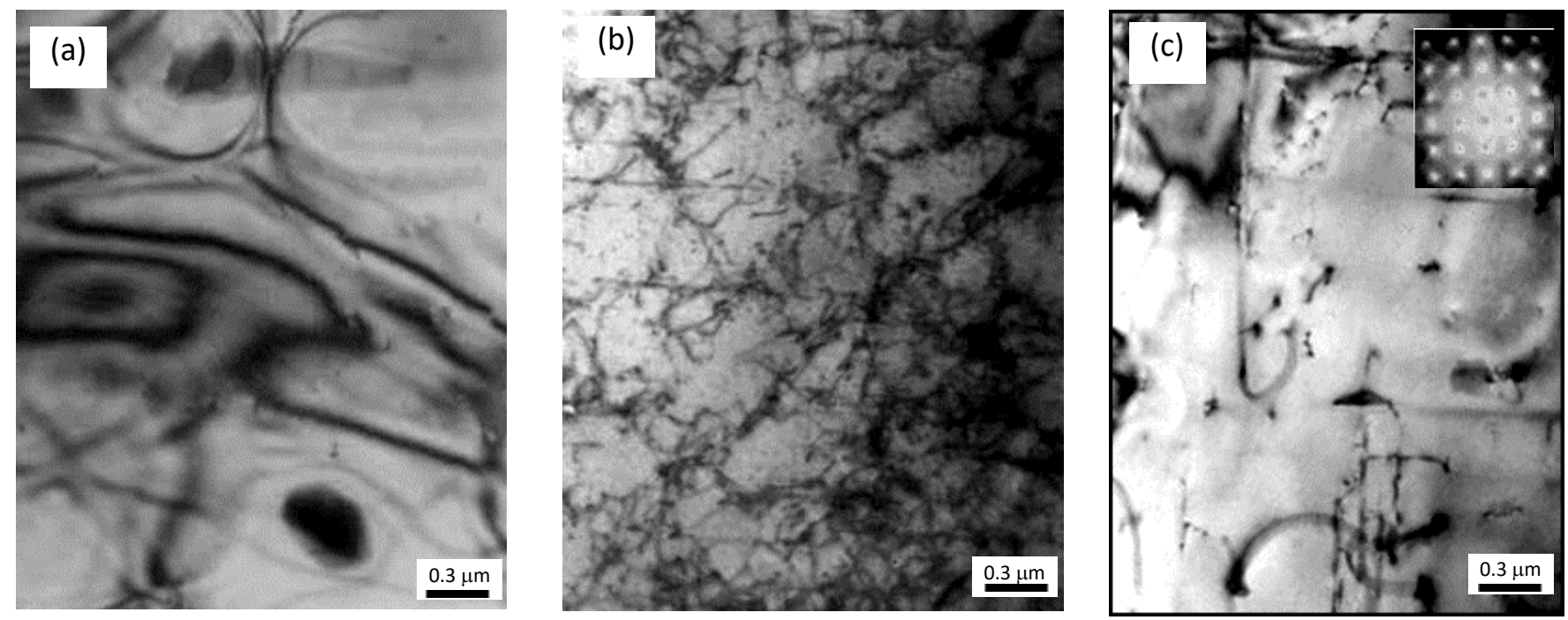

Figure 2: TEM bright-field images of overaged Al-6505 alloys at $300^{\circ} \mathrm{C}$ for (a) 0.1 hour, (b) 1 hour and 100 hours. Electron beam is in the [100] matrix direction.

\section{Conclusion}

As conclusion, the most noticeable feature is that the time to reach peak hardness and peak hardness values decreased as the ageing temperatures increased. The formation of hardening needle-shaped precipitates results in increased the hardness properties of the Al6505 alloy. Prolonged ageing time resulted in decreased in the number density of needle-shaped precipitates which led to a lower hardness properties of the Al-6505 alloy.

\section{References}

Aiza Jaafar, C.N., Azmi R., Zuhailawati, H., Ismail Z,. (2011) Effect of Mg, Si and Cu content on the microstructure of dilute 6000 series aluminium alloys, Journal of Alloys and Compounds, 509, 8632- 8640

Aiza Jaafar, C.N., Ismail Z., Harun, M., Yazid., A.A. (2013). Relationship between the microstructure and property of Al-0.21 wt $\% \mathrm{Mg}$ $0.41 \mathrm{wt} \%$ Si alloy, Malaysian Journal of Microscopy, 9, 42-46.

Aiza Jaafar, C.N., Ismail Z., Mohamad Sapri1, M.A.Z. (2015). The Effects of Thermal Ageing on Properties and Microstructure of Al-6063 Alloy, Key Engineering Materials, 694, 111-115

Emma, S., Salem., S. (2010).The heat treatment pf Al-Si-Cu-Mg casting alloys, Journal of Materials Processing Technology, 210, 249-1259

Polmear, I.J. (2017). Light Alloys from traditional alloys to nanocrystals. $5^{\text {th }}$ edition, Oxford: Butterworth Heinmann.

Zhenguo L., Zhijun Z., Guangwen Z., Pizhi Z., Warren J. P. (2021). The effect of Mg and Si content on the microstructure, texture and bendability of Al-Mg-Si alloys Materials Science \& Engineering A, 814. 